\title{
DET FORUDSIGELIGES UFORUDSIGELIGHED
}

Refleksioner over feltarbejdet som forskningsstrategi

\author{
Marianne C. Qvortrup Fibiger
}

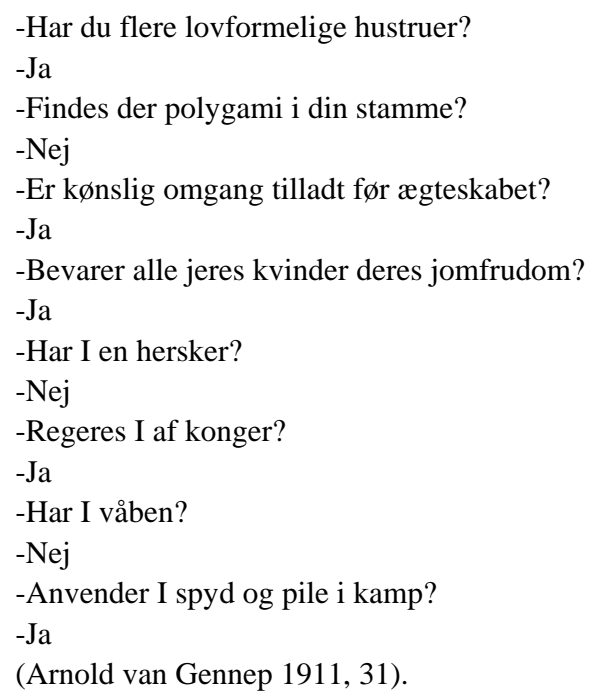

Inden for det seneste årti eller to synes der at have været en øget interesse for at gøre brug af antropologisk metode - ikke blot i studiet af religion, men i mange andre kulturvidenskabelige discipliner. Man er blevet bevidst om betydningen af at indsamle empirisk materiale der, hvor det er muligt, hvilket herefter kan indgå i undersøgelsen af det fænomen, man ønsker at beskrive. Det har samtidig betydet, at man inden for de antropologiske rækker for alvor er begyndt at diskutere eller bestemme antropologien som en videnskab (se fx Hammersley og Atkinson 1983 eller Hastrup og Ramløv 1988). Ligesom den nok mest skrivende danske antropolog Kirsten Hastrup her i år har skrevet en bog om humanvidenskab som sådan, hvor den antropologiske tilgang er stærkt repræsenteret (Hastrup 2000).

Feltarbejde, der er en central kategori inden for antropologien, er omdrejningspunktet for denne artikel, hvor jeg vil diskutere både det store mulighedspotentiale, som feltarbejde udgør, og de store faldgruber, som det indebærer. Det er vigtigt, at man er sig disse faldgruber bevidst, for at man kan bruge materialet på en ansvarlig måde. I en applicering af den antropologiske metode på det religionsvidenskabelige felt berører det desuden et helt centralt problem, som jeg også vil forholde mig implicit til: Hvad gør man der, hvor ens informanters brug eller forståelse af traditionens centrale begreber ikke stemmer overens med de tekstlige kilder eller de almindelige regler for oversættelsen af dem? Hvilken kilde skal tillægges størst autoritet? Er det evt. nok blot at resigne- 
re og tale om traditionens løbende forandring eller om lokaltraditionens særegne træk? Eller skal man løfte en filologisk, historisk eller tematisk pegefinger og understrege over for dem, der lever i den specifikke tradition, at de ikke følger de rigtige spilleregler, og at de bare har at indordne sig under de givne klassifikationsmønstre? ${ }^{1}$ Det sidste spørgsmål berører forholdet mellem en antropologisk og en historisk tilgang til en nutidig religion med rødder langt tilbage i historien. Et skisma, som jeg selv har været ude for i mit arbejde med den nutidige hinduisme både i Danmark, England, Kenya, Punjab og Sri Lanka - alle steder, hvor jeg har udført kortere eller længerevarende feltarbejde. Derfor er det nærliggende for mig også at diskutere forholdet mellem den antropologiske og historiske metode i denne artikel.

\section{Antropologisk metode}

Feltarbejde udgør som nævnt det centrale omdrejningspunkt inden for den antropologiske metode. Men feltarbejde er ikke blot en neutral måde, hvorved man får noget materiale i hænde, som man senere kan analysere og fortolke, det er også en erfarings- og erkendelsesproces, hvor man ikke blot igennem erfaringen med den givne kultur lærer den at kende, man flytter sig eller forføres også i processen. Og fordi man møder kulturen udefra og med en gadamersk forudforståelse ${ }^{2}$ qua sit eget kulturelle tilhørsforhold, så kan denne erkendelsesproces ikke undgå at være styret på forhånd. Der er med andre ord træk i den givne kultur, man er blind for, ligesom man lukker øjnene for det, man ikke ønsker at se, for at det billede, man har dannet sig på forhånd, ikke skal krakelere, eller ens tese evt. forkastes. Tilsvarende vil man slet ikke lægge mærke til det, der ligner ens egen kultur for meget. Men fordi man står udenfor, betyder det samtidig, at man også kan afdække det, kulturen selv kan være blind for. Og fordi man har med en levende empiri at gøre, kan man justere sine erkendelser undervejs ved nye og anderledes spørgsmål, efterhånden som man lærer kulturen at kende eller afkoder dens kommunikationsmønstre. Således vil det blive muligt at kunne stille de kontrolspørgsmål, der kan få helt andre - ja, endog modsvarende billeder af kulturen frem i lyset.

Et af feltarbejdets grundvilkår er, at vi er afhængige af andres informationer, og at "hvad vi som etnografer kan fatte, afhænger af det rum, de andre er parate til at dele med os” (Hastrup 1992, 78). Dette indicerer, at ved siden af en erfaret viden, vil der

\footnotetext{
${ }^{1}$ Her tænker jeg ikke så meget på fx Edward Saids orientalismekritik i hans bog Orientalism fra 1978, hvor han kritiserer den måde, hvorpå Vesten projicerer sin specifikke diskurs over på de orientalske kulturer, hvorved de stereotypiseres, men på den situation, hvor en nulevende repræsentant for en given religion forholder sig til sin religion på en sådan måde, at den ikke stemmer overens med religionens eget traditionelle bagland alias helligtekster, begreber o.l. Dvs. der hvor nogle givne klassifikationsmønstre er blevet til døde metaforer.

${ }^{2}$ Gadamer understreger at mennesket tolker verden ud fra en forudforståelse (“Vorverständnis”), der udspiller sig i sprogets univers, idet han mener, at menneskets verden totalt set er sprogligt formidlet. Menneskets forståelse er ikke blot cirkulær, mener Gadamer, men antager snarere en spiralstruktur, hvorved intet menneske kan undslippe sin forståelseshorisont, den kan kun udvides eller korrigeres (1960).
} 
altid findes en skjult viden, som feltarbejderen muligvis aldrig bliver indviet i; enten fordi den for informanterne synes irrelevant eller for dem umiddelbart synlig, eller fordi feltarbejderen og informanterne tager udgangspunkt i så forskellige begrebs- og erfaringsverdener, at kommunikationen mellem de to kan bero på misforståelse, som indledningscitatet indicerer. Her blev misforståelsen dog afbødet ved kontrolspørgsmål, der tager udgangspunkt i informanternes egen verden, og som kun kan komme feltarbejderen i hænde, hvis han/hun har delt en social erfaring med dem. Det betyder på den ene side, at feltarbejderen eller etnografen henter sit materiale der, hvor en given religion og/eller kultur er, samtidig med at han/hun påvirker sit materiale ved at lade sig indskrive i de andres rum. Hun kan således aldrig optræde som en flue på væggen, men er ved sin blotte tilstedeværelse med til at påvirke sit eget indsamlede materiale. Således "flytter sandheden sig i forskningsprocessen - og på grund af den” (Hastrup og Ramløv 1988, 8).

Dette berører på den ene side feltarbejdets kompleksitet og relativitet og dermed dets sandhedsværdi, men det berører på den anden side også det mulighedspotentiale som de(n) antropologiske metode(r) har, og som for mig at se adskiller den fra de(n) historiske metode $(r)^{3}$ - metode bliver her forstået som en planmæssig fremgangsmåde, hvorved vi tilvejebringer, analyserer og fortolker dokumenter. Eller sagt med andre ord: metodevalg afhænger af, hvad man ønsker at undersøge eller tilvejebringe af dokumentation. Det betyder ikke blot, at det materiale, som henholdsvis den antropologiske og den historiske metode forholder sig til, bliver forskelligt, det gør også deres fokus, og derfor bliver deres beskrivelse af fx en specifik religion heller ikke ens. Jeg vil senere i artiklen argumentere for en metode-bricolage, hvor det for mig at se bliver mere og mere påkrævet at gøre brug af flere metoder, når man undersøger komplekse fænomener i en verden kendetegnet ved hybriditet og hastige forandringer. Jeg vil ikke lægge op til en tilfældig eklektisk shopping mellem forskellige metoder, men et bevidst valg af metode i forhold til, hvad man ønsker at undersøge, og hvor man er i forskningsprocessen.

Deltagelse og observation er to af grundpillerne i feltarbejdet. Deltagelse kræver en indlevelse i de andres rum, både fysisk og psykologisk. Observation derimod kræver distancering, så man nøgternt kan registrere de faktuelle forhold, der har betydning for de handlingsmønstre, der er til stede. Man skal forsøge at balancere mellem disse yderpoler. På den ene side skal man ikke 'go native', på den anden side skal man forstå de mekanismer, der ligger bag en udtryksform. Det kræver en indskrivning i de andres rum. Men ved at spille med sætter man, med Hastrup og Ramløvs ord, sig selv på spil. Dvs. at der uvægerligt opstår relationer mellem feltarbejderen og de andre, der påvirker hele situationen og dermed det indsamlede materiale. Alligevel mener jeg, at feltarbejde er en vigtig forudsætning, når man har med levende religioner at gøre, for, som Hastrup og Ramløv i ovenstående citat antyder, er et af kulturforskningens grundvilkår, at ligesom sandheden flytter sig i forskningsprocessen, på samme måde flytter sandheden sig i

\footnotetext{
${ }^{3}$ Metode som sådan er ikke noget entydigt begreb og kan variere både inden for antropologien og historien, hvorfor der egentlig bør tales om metoder inden for hvert område, og hvor ingen metode i absolut forstand kan siges at have monopol på sandheden.
} 
det levende liv. Altså en understregning af det dialektiske forhold, der er til stede, og den gensidige påvirkning, der finder sted mellem individ(er) og samfund på et givent sted og på et givent tidspunkt. Det er gennem feltarbejdet, at man skal forsøge at afprøve sine forudfattede ideer og det materiale, man har konsulteret på forhånd, så det ikke står i et modsætningsforhold til kulturens eget betydningssystem.

Som Niels Fock $(1988,187)$ understreger, udspringer ethvert etnografisk materiale af en unik social situation. Derfor kan man aldrig bringe etnografisk feltarbejde på en almen formel. Tilsvarende vil forskellige feltarbejder foretaget af den samme forsker blandt den samme gruppe mennesker ofte falde forskelligt ud. Fx oplevede jeg et tydeligt positionsskifte i forbindelse med mit feltarbejde blandt srilankansk-tamilske hinduer her i landet fra før og efter, jeg havde lavet feltarbejde i Sri Lanka. Før jeg tog afsted, var jeg novicen, som man tålmodigt belærte og tillod at stille tilsyneladende banale spørgsmål. Efter jeg kom hjem, var jeg blevet eksperten, der tilsyneladende blot skulle høre, om de kunne deres lektie. De troede, jeg vidste bedre, og blev derfor mere forsigtige med deres udtalelser. Dvs. man kan aldrig læse sig til en specifik metode, men blot ruste sig ved at læse om andres erfaringer eller ved at høste af sine egne. Det betyder, som Vibeke Steffens $(1995,15)$ gør rede for, at der er skrevet mange bøger om antropologers oplevelser og erfaringer i felten og de deraf følgende refleksioner, mens der findes forholdsvis få bøger med anvisninger på fx dataindsamlingsteknikker (jf. fx Spradley 1979; 1980 og Ellen 1984). Med andre ord udgør ethvert feltarbejde en unik situation, hvor de vigtigste informationer ofte opstår der, hvor man mindst regner med dem, i en ikke iscenesat objekt-subjekt relation, og der hvor man ikke selv er herre over kommunikationen. Fx nævner Anne Knudsen (1995, 24), at de bedste interviews, hun har foretaget, ofte foregår i en bil. Her er man for en stund adskilt fra den virkelighed, som man taler om. Bilen skaber et neutralt rum. Tilsvarende har jeg ofte fået centrale informationer der, hvor jeg har udført et konkret stykke arbejde sammen med min informant. Dvs. at vi begge er fikseret på noget, der ligger ud over det, vi egentlig taler om. Selvfølgelig skaber det en anden form for dokumentation, da man hverken har båndoptageren tændt eller notesblokken parat, men det skaber et springbræt for senere, mere formelle interviews. Netop derfor "handler antropologisk metode i høj grad om forskerens erfaring i felten; en personlig erfaring, som næppe lader sig standardisere i metodiske læresætninger, der systematisk kan videregives til kommende antropologer” (Steffens 1995, 15). Dvs. at antropologisk metode snarere kan anses for at være en mulig forskningsstrategi frem for en fastsat teknik.

I en artikel fra 1995 forsøger Jonathan Friedman dog på trods heraf at strukturere eller systematisere den antropologiske metode. Det gør han med udgangspunkt i Karl Mannheims værk: Strukturen des Denkens fra 1922 (genudgivet i 1980), som han herefter forfiner. Mannheim sondrer imellem, hvad han kalder den konjunktive og den kommunikative erfaring. Den konjunktive erfaring henviser til det fælles reservoir af forforståelser, som er udgangspunkt for en implicit viden blandt en given gruppe af mennesker, og som danner udgangspunkt for, hvad man kan kalde kulturfrembringelse, idet den konjunktive erfaring danner udgangspunktet for en normativ organisering af samfundet og dets indbyrdes sociale relationer. Den kommunikative erfaring derimod hen- 
viser til de almindelige former for kommunikation, til erkendelse og til fortolkningen af erkendelsen, hvilket mere eller mindre hører den eksplicitte viden til. Overordnet kan man se den konjunktive erfaring som det erfaringsgrundlag, den kommunikative erfaring er abstraheret fra, og som kommer til udtryk i de socialt styrede indkodede strukturer. Som konklusion på sin metodediskussion opstiller Friedman fem punkter (s. 18687), som han anser for centrale for feltarbejdet, hvis mål det er at kunne kortlægge eller konstruere de fælles betydninger, som en given gruppe mennesker har (her gengivet $\mathrm{i}$ min noget forkortede form):

1) Feltarbejde er en strategi til at dokumentere andre folks erfaringsverden, handlen og betydningsfrembringelse med.

2) Feltarbejde er, i kraft af en optegnelse af hændelser, udsagn og historier/fortolkninger, en dokumentationsmåde for de mere håndgribelige relationer mennesker og grupper imellem.

3) Feltarbejdet afhænger af, om man formår at etablere nære relationer til dem, man arbejder iblandt. Her kan man blot konstatere, at nogle feltarbejdere er bedre til dette end andre.

4) Etableringen af sociale relationer er både væsentlig og mulig pga. det antropologiske projekts natur, der handler om mennesker og deres sameksistens og ikke om en absolut Andethed.

5) Som feltarbejder laver man nogle forståelsesrammer, som man organiserer og fortolker sit materiale indenfor. Disse rammer skal dog være eksplicitte nok til at kunne blive falsificeret af de forhåndenværende dokumenter. Samtidig kræver det også, at man inddrager andre former for dokumentation, som ikke tilvejebringes af feltarbejdet, men som er nødvendige at inddrage, for at man kan få så fyldestgørende et billede af kulturen som mulig. Her nævner Friedman fx historiske og statistiske dokumenter.

\section{Samspillets komplementaritet}

I studiet af menneskelige kulturer forskellige fra vor egen har vi at gøre med et ejendommeligt iagttagelsesproblem, som nærmere betragtet udviser mange fællestræk med de atomfysiske eller psykologiske problemer, hvor henholdsvis den uundgåelige vekselvirkning mellem objekterne og måleinstrumenterne og umuligheden af at skelne skarpt mellem et objektivt indhold og et iagttagende subjekt hindrer den umiddelbare anvendelse af de til dagliglivets erfaringer tilpassede forestillinger. ${ }^{4}$

I dette citat beskriver Niels Bohr menneskelige relationer ud fra atomfysikkens komplementaritetsteori, der understreger, at en fuldstændig beskrivelse af et fysisk fænomen oftest kun kan opnås gennem skiftende synsvinkler, der på trods af, at de eventuelt udelukker hinanden, er med til at supplere og ikke mindst komplementere hinanden. Niels Fock understreger i en artikel om feltarbejdets komplementaritet, hvorfra ovenstående

${ }^{4}$ Niels Bohr, Atomfysik og menneskelig erkendelse, København 1959, s. 43; her citeret efter Fock 1988, $187-$ 88. 
citat er hentet, at komplementaritet nok er den vigtigste fælles strukturelle kvalitet, der findes i feltarbejdersituationen, efter at man har forladt det entydige billede af forholdet mellem feltarbejder og informant(er), som en objekt-subjekt relation. Man skal i stedet forsøge at finde en syntese i en situation, hvor både man selv og de folk, man studerer, hele tiden skifter position (Fock 1988, 188). ${ }^{5}$

Grunden til at komplementaritet spiller så stor en rolle inden for antropologien er, at man indgår i den sociale situation. Man kan nærmest sige, at delt social erfaring ${ }^{6}$ kan karakteriseres som en metodisk indfaldsvinkel, hvor opmærksomheden rettes mod etnografens bevidste tilstedeværelse. Det er et nødvendigt ræsonnement, da etnografen henter sit empiriske materiale der, hvor menneskene er. Begrebet delt social erfaring hænger således sammen med en refleksivitet, der foregår i et samspil mennesker imellem, og er derfor noget ganske andet end tekstlig refleksivitet. Eller med Peter Herviks $(1995,66)$ ord, er det kun derved, at vi kan nå frem til refleksiviteten - vel at mærke i antropologisk forstand. Det er med andre ord erfaringen, der knytter refleksiviteten sammen med antropologisk viden.

Den kognitive antropologi er en af de vigtigste tilgange til analysen af sociale erfaringer. Den henviser til de mønstre i vores referencerammer, vi bruger til at ræsonnere med i konkret interaktion. Den kognitive antropologi taler om de såkaldte skemaer, som er de kognitive repræsentationer, der skabes ved interaktion med omverdenen. Hvis sådanne skemaer deles af flere, kan man tale om kulturelle modeller. De er ikke lagret i hjernen en gang for alle, men fungerer snarere som fleksible kulturelle redskaber, folk anvender i praksis, og som kommer til udtryk i interaktionen (Hervik 1995, 68). Men det betyder samtidig også, at der opstår et tredje rum, hvor både feltarbejderne og informanterne træder ud af deres vante positioner. De påvirker gensidigt hinanden i den kunstige situation, begge parter befinder sig i. Her opstår den komplementaritet, som man ikke må lade ude af betragtning i sin analyse. Feltarbejderens spørgen eller deltagelse betyder, at hun selv er med til at præge de informationer, hun får. Med andre ord er man en del af det materiale, man indsamler. Samtidig er feltarbejderens specifikke spørgsmål eller bestemte adfærd med til at præge informanterne for stedse, når de træder ud af det tredje rum igen. Forandringen ligger bl.a. i, at et tidligere nonverbalt adfærdsmønster som fx et ritual beskrives tekstligt, hvorved det objektiveres. Dermed indtræder det i informanternes bevidsthed på en helt anden måde end tidligere. Tilsvarende har jeg oplevet, hvordan mine egne tekstuelle beskrivelser i forbindelse med en

\footnotetext{
${ }^{5}$ Tilsvarende overvejelser ligger implicit i Anthony Giddens' ide om den dobbelte hermeneutiske proces, som han mener er til stede inden for de videnskaber, der analyserer samfundet. I disse videnskaber observerer og fortolker forskeren en virkelighed, der allerede er blevet fortolket af de personer, der udgør forskerens genstand (1982).

${ }^{6}$ Som Peter Hervik (1995) gør rede for, er det vigtigt at man skelner imellem social erfaring og delt social erfaring. Social erfaring implicerer tilstedeværelsen af to eller flere personer i et specifikt socialt rum, men hvor de ikke behøver at have nogen form for meningsudveksling eller at have nogen form for kulturel udveksling. Delt social erfaring derimod kræver, udover at man deler et socialt rum, også at man gensidigt lader sig engagere og tillader, at man forandrer sig i processen (se fx s. 74).
} 
klargøring af et givent handlingsmønster senere indgår som informanternes egne forklaringer, når de over for andre skal gøre rede for deres tradition. Som eksempel kan jeg nævne, at jeg stødte på en af mine udlægninger af en given tempelpraksis i et referat, som en gymnasieklasse, der havde været på ekskursion til templet i Herning, havde lavet, og som de havde fået fortalt (eller snarere genfortalt) af et af bestyrelsesmedlemmerne der. Min tolkning af tempelpraksis var indoptaget og blevet deres. Feltarbejderen efterlader sig på denne måde blivende spor. Hun kan aldrig optræde som fluen på væggen, for som observatør bliver man automatisk deltager.

I denne synsvinkel om gensidig påvirkning og komplementaritet ligger der fire fundamentale områder, som skal tages med i betragtning, når man analyserer sit indsamlede materiale:

1) Når man laver feltarbejde, lader man sig indskrive i de andres rum, som ændrer sig ved ens tilstedeværelse. Dvs. man bliver en del af sit eget indsamlingsmateriale.

2) Man skaber en ny virkelighed. Ved sin tilstedeværelse, sine spørgsmål og fortolkninger sætter man ord på et liv, der aldrig var ment som tekst.

3) Forholdet til den virkelighed, man ønsker at beskrive, ændrer sig i processen - både for én selv og for ens informanter.

4) Den kultur eller det samfund, man beskriver, hører allerede historien til. Det skyldes både den kendsgerning, at tradition er under permanent forandring, og at man i kraft af sin egen tilstedeværelse og spørgsmål kan have sat gang i en refleksion, der kan have indflydelse på forholdet til traditionen, hvorfor billedet ændrer sig i takt dermed.

Komplementaritet er et element, der må tages højde for i antropologisk metode. Samtidig giver den også adgang til såkaldt skjult information, hvorved kulturens eget betydningssystem afdækkes.

\section{Det blinde øjes optik}

No man ever looks at the world with pristine eyes. He sees it edited by a definite set of customs and institutions and ways of thinking. Even in his philosophical probings he cannot go behind these stereotypes; his very concepts of the true and the false will still have reference to his particular traditional customs (Benedict 1959, 18).

Udover den gensidige påvirkning, der finder sted imellem feltarbejder og informant/ kultur, er det også af væsentlig betydning, hvilket billede man på forhånd, både bevidst og ubevidst, har dannet sig af kulturen. Hvad forventer man at møde? Man har på forhånd mere eller mindre ubevidst dannet konturerne af det billede, man senere redegør for. Jeg kalder det 'det blinde øjes optik'. Det er en optik, som ens egen kulturelle baggrund har været med til at forme. Selv om man forsøger at distancere sig fra sin kulturelle baggrund, er man bundet til den - også i negationen af den. Nogle fænomener har man med sit kulturbestemte blik ikke øje for. Og det blinde øje vendes også mod det, man ikke ønsker at se. Samtidig søger man efter analogier, der korresponderer med det, 
man allerede kender i oversættelsen af det fremmede. Man gør således brug af egen traditions vokabular i et forsøg på at forstå. Man tror, man har forstået, men gør det ikke. Oversættelsen bliver misvisende. Det er, som Crapanzano $(1986,51)$ siger det: "Like translation, ethnography is also a somewhat provisional way of coming to terms with the foreignness of languages - of cultures and societies”. Det får ham til at sammenligne etnografen med Hermes:

The ethnographer is a little like Hermes: a messenger who, given methodologies for uncovering the masked, the latent, the unconscious, may even obtain his message through stealth. He presents languages, cultures, and societies in all their opacity, their foreignness, their meaninglessness; then like the magician, the hermeneut, Hermes himself, he clarifies the opaque, renders the foreign familiar, and gives meaning to the meaningless. He decodes the message. He interprets (ibid.).

Som feltarbejder er det vigtigt, at man er sig udvælgelsesarbejdet og tilgangen til det empiriske arbejde bevidst. Det er helt, som det ovennævnte citat markerer: Man er i sit oversættelses- og udvælgelsesarbejde som en Hermes-figur, men er man sig denne rolle bevidst, kan man også få nye træk frem i lyset, som den iagttagede religion eller kultur ikke selv er bevidst om. Samtidig skal man overbevise læseren om fortolkningens sandhedsværdi. Og her opstår for mig at se det springende punkt inden for den antropologiske tilgang, for man kan på ingen måde bevise, at man ikke har observeret skævt, at ens analyser og oversættelser af fx ens informanters udtalelser og deres udlægning af traditionen har hold i virkeligheden. Der findes med andre ord ikke noget dokument at henvise til, hvis man vel at mærke ikke har båndet udtalelsen. Det berører feltarbejdets sandhedsværdi, men det skaber samtidig også et klart billede af den indre dynamik, der bør være til stede i enhver kulturel refleksion.

Man kan dog håbe på, at forskerens materiale og omgang med sit materiale taler for sig selv, så formidlingen eller interpretationen bliver transparent, forstået på den måde, at sandhedsværdien eller kilderne skinner igennem tolkningen af dem. Men det betyder samtidig også, at man skal være bevidst om, at en antropologisk monografi ikke kan underlægges de samme kriterier for kritik, som fx en historisk analyse af en given helligtekst. Den er, som Jonathan Friedman skriver det: "et altid-allerede fortolket værk som vanskeliggør, for ikke sige, umuliggør at materialet kan underkastes et andet synspunkt” $(1995,185)$. En antropologisk-orienteret monografi er med andre ord et specifikt nedslag i historien på et givent sted og hos en repræsentativ gruppe af en given lokalkultur og i en given kontekst, hvor man ikke kan udelukke en evt. bagvedliggende skjult dagsorden. Således er den antropologiske monografi en konstruktion af en kultur, som fremstilles i en given social kontekst og i den interaktion, der opstår mellem informanterne, omgivelserne og feltarbejderen selv.

Netop derfor er det så vigtigt, at man er sig bevidst om de usikkerhedsmomenter, som det indsamlede materiale på forhånd er dømt til at være underlagt: 1) Distancering, kulturen skilles ud som noget anderledes og adskilt fra en selv. 2) Selektion. Både en bevidst og en ubevidst udvælgelse af det materiale, som senere udgør fundamentet $i$ en 
analyse. 3) Strukturering af indtryk ud fra forventninger og forudindfattede ideer. 4) En usynlig fundering i egen kultur. 5) Oversættelsen sker ud fra et traditionsbundet vokabular, ligesom det der udtales, og hvad der udtales om er person- og kontekstbundet. 6) Materialet er bundet til et givent nedslag i historien og i en given social situation. 7) Sigtet med undersøgelsen. Hvad er det, man håber at vise?

\section{Det skrevne sprog}

Religionshistorikeren tager oftest udgangspunkt i det skrevne sprog som kilde. Den oversættes, kategoriseres og fortolkes, så den kan bruges som springbræt til en bredere refleksion over enten en bestemt religion eller til en bredere religionsfænomenologisk analyse af religion som sådan. Men til forskel fra det antropologiske arbejde, er det ikke ud fra en antropologisk synsvinkel muligt for historikere selv at skabe kilder (jf. Ginzberg 1999, 145 - et synspunkt, der dog kan anfægtes, når det gælder fx samtidshistorikere). De kan finde nye ved at grave i arkiverne, men hvor teksterne ikke taler, kan de stort set ikke udtale sig. De kan ganske vist omfortolke gamle kilder via nye, forholde dem til den kontekst, de er blevet nedskrevet i, diskutere forholdet mellem mundtlig og skriftlig overlevering, men de kan ikke gå i direkte dialog med teksterne og stille evt. kontrolspørgsmål, hvor der opstår diskrepanser eller evt. huller i den konstruktion af en forgangen virkelighed, man er i færd med at lave. Og fordi historikeren har med tekst at gøre, har hun med en materialiseret og allerede fortolket beskrivelse af verden at gøre. Således findes der ikke neutrale tekster (op.cit., 149). ${ }^{7}$

Samtidig berører Carlo Ginzberg de mange lighedspunkter, der findes imellem det antropologiske og det historiske materiale, hvorved han plæderer for en etnografisk historie, hvor han sammenligner historikeren med en jæger, der leder efter spor, eller detektiven, der leder efter indicier. Som han selv siger, skal man anskue sporene som en sproglig fortcetning af en historisk proces (op.cit., 86). Desforuden har sproget også sin naturlige begrænsning, hvilket betyder, at ikke alt kan udtrykkes i det skrevne sprog. Man kan derfor med rimelighed påstå, at en stor del af den kulturelle erfaring finder sted uden for sproget. Sproget er vigtigt, men det kan ikke føre os ind i alle de kulturelle modeller og i en given habitus, der hvor denne udspringer af, hvad der kan kaldes de ubevidste sedimenter af erfaring.

Fordi historikeren har med tekster at gøre, betyder det også, at den historiske hermeneutik kan underlægges en helt anden form for kontrol end en antropologisk monografi kan det. Man kan gå til kilden og diskutere, om historikeren har læst sine kilder korrekt, og om denne burde have konsulteret andre kilder for at få et mere nuanceret billede på de beskrevne fænomener. Men til forskel fra den antropologiske metode har den historiske metode også fordelen ved - via sine kilder - at kunne gå synkront tilværks, ligesom

\footnotetext{
${ }^{7}$ Denne kendsgerning ser Ginzberg som et opgør med en naivt-positivistisk epistemologi, som alt for mange historikere stadig hælder til (1999, 147).
} 
den kan udsige noget om den tradition, som evt. nuværende kulturelle udtryksformer hviler på.

\section{Feltarbejderen som både ingeniør og bricoleur}

I Den vilde tanke fra 1962 (1994) polemiserer Lévi-Strauss i hele kap. 9: "Historie og dialektik" imod Sartres dialektiske historieforståelse, sådan som han fremstiller den i Critique de la Raison dialectique. Skønt både Sartre og Lévi-Strauss begge tager udgangspunkt i en marxistisk terminologi, har de vidt forskellige forestillinger om, hvad fx den dialektiske fornuft er, hvad den kan udsige, og ikke mindst hvor historien bør placeres i forhold til andre humanistiske videnskaber. Ifølge Lévi-Strauss tillægges den dialektiske fornuft en realitet sui generis hos Sartre, en fornuft der eksisterer uafhængigt af den analytiske fornuft, enten som dens modpol eller som dens komplementære modsætning. Lévi-Strauss understreger, at modsætningen mellem disse to former for fornuft er relativ, ikke absolut. For Lévi-Strauss dækker udtrykket den dialektiske fornuft over "de anstrengelser, som den analytiske fornuft stadig må gøre sig for at forny sig, hvis den vil gøre krav på at forklare sproget, samfundet og tanken; og adskillelsen mellem de to former for fornuft ligger for os at se kun i det tidsmæssige skel, der ligger mellem den analytiske fornuft og forståelsen af livet" (Lévi-Strauss 1994, 247). Og han slutter i denne forbindelse med at konkludere, at "vi må derfor, som Sartre anbefaler, anvende den dialektiske fornuft i erkendelsen af vort og andres samfund. Men vi må ikke glemme, at den analytiske fornuft spiller en betydelig rolle i dem alle, og da den nu er der, må den metode vi anvender, også gøre det muligt at finde den” (op.cit., 252f).

Anerkendelsen af både den analytiske og den dialektiske fornuft er samtidig også anerkendelsen af, at flere optikker bør anvendes pga. bricolage, dvs. materialets uforudsigelighed. Og overført til denne artikels metodediskussion, er det for mig at se en anerkendelse af, at brugen af flere tilgange skaber en bredere forståelse. Det kan underbygges ved, at Lévi-Strauss også tillægger etnologien og historien lige stor berettigelse:

Etnologen respekterer historien, men tillægger den ikke nogen større værdi på bekostning af de andre (underforstået humanvidenskaberne). Han opfatter den som en forskning, der kompletterer hans egen: den ene folder viften af menneskelige samfund ud i tid, den anden i rum. Og forskellen er endnu mindre end det skulle synes, eftersom historikeren søger at rekonstruere billedet af forsvundne samfund således som de var i øjeblikke, der for dem var nutid; medens etnografen gør sit bedste for at genopbygge de etaper af historien, der i tid er gået forud for de nuværende former (op.cit., 257).

Bricolage er en substantiveret form af verbet bricoler, der beskriver en uregelmæssig eller utilsigtet bevægelse, og som blev brugt i boldspil og billard og inden for jagtsprog og ridning. Ligesom en bricoleur er en, der arbejder med sine hænder, men som går andre veje eller omveje sammenlignet med fagmanden, så karakteriserer Lévi-Strauss den mytiske tanke og refleksion som ligeså uforudsigelig og uensartet (op.cit., 27). Tilsvarende er det materiale, vi har med at gøre som religionsforskere, der er underlagt 
bricoler. Derfor kræver vores materiale flere tilgange. Der er brug for både et diakront og et synkront studium af religion, vel at mærke der, hvor det er muligt.

For at kunne omgås det materiale, der i sig skjuler muligheden for bricolage, må feltarbejderen selv være en bricoleur. Hun skal turde gå nye eller andre veje for at afdække eventuelt skjult viden. Men hun kan ikke være bricoleur, hvis ikke hun samtidig er ingeniør, dvs. følger en på forhånd valgt metodisk tilgang, der fungerer som den røde tråd igennem arbejdet. Således sættes ikke blot komplementariteten mellem kilden og forskeren i spil, men også komplementariteten mellem de to yderpositioner, som man bevæger sig mellem: Den forudsigelige ingeniør-position, der følger en bestemt skabelon for at frembringe et ønsket materiale, og bricoleur-positionen, der tør udfordre og dermed skabe mulighed for, at det uforudsigelige ikke blot bringes i spil, men også inddrages som centralt materiale.

\section{Konklusion}

Jeg har i det foregående gjort rede for feltarbejde som en central del af den antropologiske metode, som jeg har anvendt i min tilgang til hinduisme. Jeg har gjort rede for dens muligheder og begrænsninger og understreget, at vi her har med en helt anden type kilder at gøre, end dem vi sædvanligvis som religionsforskere studerer. Det er kilder, der er unikke, da de dannes i en specifik social situation, der aldrig kan genskabes, og som ofte bliver til i en dialog mellem forskeren selv og repræsentanter for den religion, man ønsker at få et større indblik i. Det medfører, at vi skal omgås disse kilder på en anden facon, end når vi har med historiske kilder at gøre, ligesom vi ikke kan stille de samme krav til dem. Deres autencitet kan med andre ord ikke bevises, men dog anfægtes eller problematiseres af dem, der ikke har været til stede i det sociale rum, hvorfra materialet udsprang - dvs. eventuelle kritikere af en antropologisk monografi. Det betyder til gengæld også, at feltarbejderen skal være meget bevidst om, hvad det er for noget materiale, hun har med at gøre, og være sig de ovenfor skitserede usikkerhedskriterier bevidst. Ligesom hun skal være klar til at stille kontrolspørgsmål til sit materiale.

I min beskrivelse af feltarbejde som forskningsstrategi lægger jeg desuden op til, at vi som religionsforskere bør gøre brug af den antropologiske metode, hvor vi har med 'levende' religioner at gøre, men ikke uden at det materiale, man herved får i hænde, går i dialog eller i diskussion med evt. tilgængeligt historisk materiale. Idet det historiske materiale ofte har en bredere repræsentativitet ved at være blevet kanoniseret eller accepteret inden for en given tradition, må det siges at have en anden status eller høre en anden kategori til. Samtidig må vi forsøge at spejle dele af det historiske materiale i nutidige udtryksformer, eller sagt på en anden måde: Fragmenternes (de historiske) betydning må søges i nutiden, i det omfang "det mønster, de tegner, kan tilpasses civilisationsformer, der eksisterer i dag” (Ginzberg 1999, 210).

Sagen er, at det er den vedvarende gensidige påvirkning, der for mig at se skaber den bedste tilgang til vores fag. Selvom det er svært - om ikke umuligt - for den enkelte forsker at bestride flere tilgange, er det vigtigt, at vi i vores forskning er os flere tilgange 
bevidst. Der er med andre ord brug for, at der stilles både hvorfor-, hvad- og hvordanspørgsmål. Det mener jeg, at en bevidsthed om bricolage giver muligheden for. Eller som Geertz $(1983,29)$ har udtrykt det: "Given the dialectical nature of things, we all need our opponents. ... What we are most in want of right now is some way of synthesizing them.”

\section{Litteratur}

BENEDICT, RUTH

1959 Patterns of Culture, New York.

CRAPANZANO, ViNCENT

1986 “Hermes’ Dilemma: The Making of Subversion in Ethnographic Description”, i J. Clifford \& G.E. Marcus, eds., Writing Culture, Berkeley, Los Angeles, London.

ELLEN, Roy F., ed.

1984 Ethnographic Research - a guide to general conduct, London.

FoCK, NIELS

1988 “Feltarbejdets komplementarietet”, i Kirsten Hastrup \& Kirsten Ramløv, eds., Feltarbejde. Oplevelse og metode i etnografien, København.

FRIEDMAN, JONATHAN

1995 “De andres erfaringer”, Antropologi 31, København, 185-190.

GEERTZ, CLIFFORD

1983 Local Knowledge. Further Essays in Interpretative Anthropology, New York.

GENNEP, ARNOLD VAN

1911 Les demi-savants, Paris.

GIDDENS, ANTHONY

1982 Sociology - A Brief but Critical Introduction, London.

GINZBERG, CARLO

1999 Spor. Om historie og historisk metode, København.

HAMMERSLEy, Martyn \& PAUL ATKINSON

1983 Ethnography. Principles in Practice, London and New York.

HASTRUP, KIRSTEN

1992 Det antropologiske projekt - om forbløffelse, København.

2000 Viljen til viden. En humanistisk grundbog, København.

HASTRUP, KiRSTEN \& KiRSTEN RAMLøv, eds.

1988 Feltarbejde. Oplevelse og metode i etnografien, København.

HerviK, PETER

1995 “Don Iz har ondt i maven. Delt social erfaring og sameksisterende refleksiviteter”, Antropologi 31, København, 65-80.

KNUDSEN, ANNE

1995 “Mercedes-modellen. Feltarbejde blandt de u-eksotiske”, Antropologi 31, København, 19-26.

LÉVI-STRAusS, ClAudE 
1994 (1969) Den vilde tanke, København.

SPRADLEY, JAMES

1979 The Ethnographic Interview, New York.

1980 Participant Observation, New York.

STEFFENS, ViBEKE

1995 "Hinsides forestillingen om det uforudsigelige. Om at være drikkende ikke-alkoholiker blandt ikke-drikkende alkoholikere”, Antropologi 31, København, 7-18.

\section{Summary}

The last decade has seen an increased interest in ethnography and anthropology among researchers of other fields who are studying culture in one way or another. At the same time ethnography and anthropology have realized the necessity of discussing their own theoretical and methological viewpoints. One of the main features in anthropological method is fieldwork. Here you participate, overtly or covertly, in people's daily lives for an extended period of time, or on special occasions, watching what is going on, listening to what is being said, asking questions, and in this way collecting data that can throw light on the issues that you are concerned about.

This article discusses fieldwork as a useful strategy in the study of religion with living representatives. It discusses the new possibilities that can be obtained by fieldwork, but also the mistakes that fieldwork can lead to if the researchers do not take into account several uncertain factors - some of which are being pointed out in the article. This means that a researcher engaged in fieldwork must be an engineer having a special methodological and theoretical intake to a specific study but, at the same time, she must take account of bricolage, being a bricoleur herself.

By using some of Carlo Ginzberg's viewpoints, this article also discusses the differences and similarities in historical and anthropological method and ends up pleading for a methodological pluralism when dealing with "living religion".

Marianne C. Qvortrup Fibiger Adjunkt, ph.d. Institut for Religionsvidenskab Aarhus Universitet 